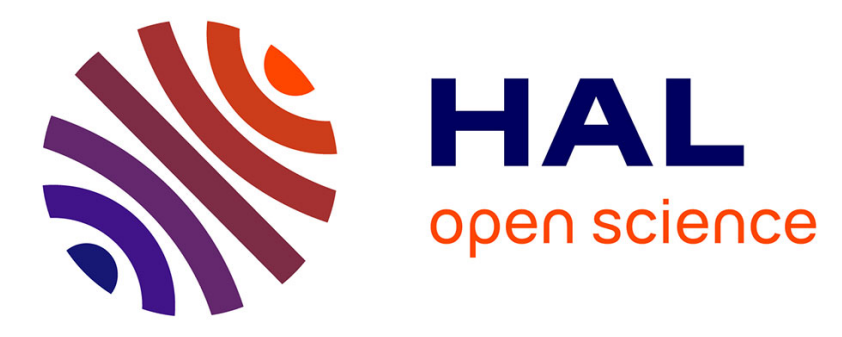

\title{
Extreme Fall 2014 Precipitation in the Cévennes Mountains
}

\author{
R. Vautard, P. Yiou, G. van Oldenborgh, G. Lenderink, S. Thao, A. Ribes, S. \\ Planton, B. Dubuisson, J.-M. Soubeyroux
}

\section{- To cite this version:}

R. Vautard, P. Yiou, G. van Oldenborgh, G. Lenderink, S. Thao, et al.. Extreme Fall 2014 Precipitation in the Cévennes Mountains. Bulletin of the American Meteorological Society, 2015, 96 (12), pp.S56 - S60. 10.1175/BAMS-D-15-00088.1 . hal-01805183

\section{HAL Id: hal-01805183 \\ https://hal.science/hal-01805183}

Submitted on 14 Jan 2021

HAL is a multi-disciplinary open access archive for the deposit and dissemination of scientific research documents, whether they are published or not. The documents may come from teaching and research institutions in France or abroad, or from public or private research centers.
L'archive ouverte pluridisciplinaire HAL, est destinée au dépôt et à la diffusion de documents scientifiques de niveau recherche, publiés ou non, émanant des établissements d'enseignement et de recherche français ou étrangers, des laboratoires publics ou privés. 


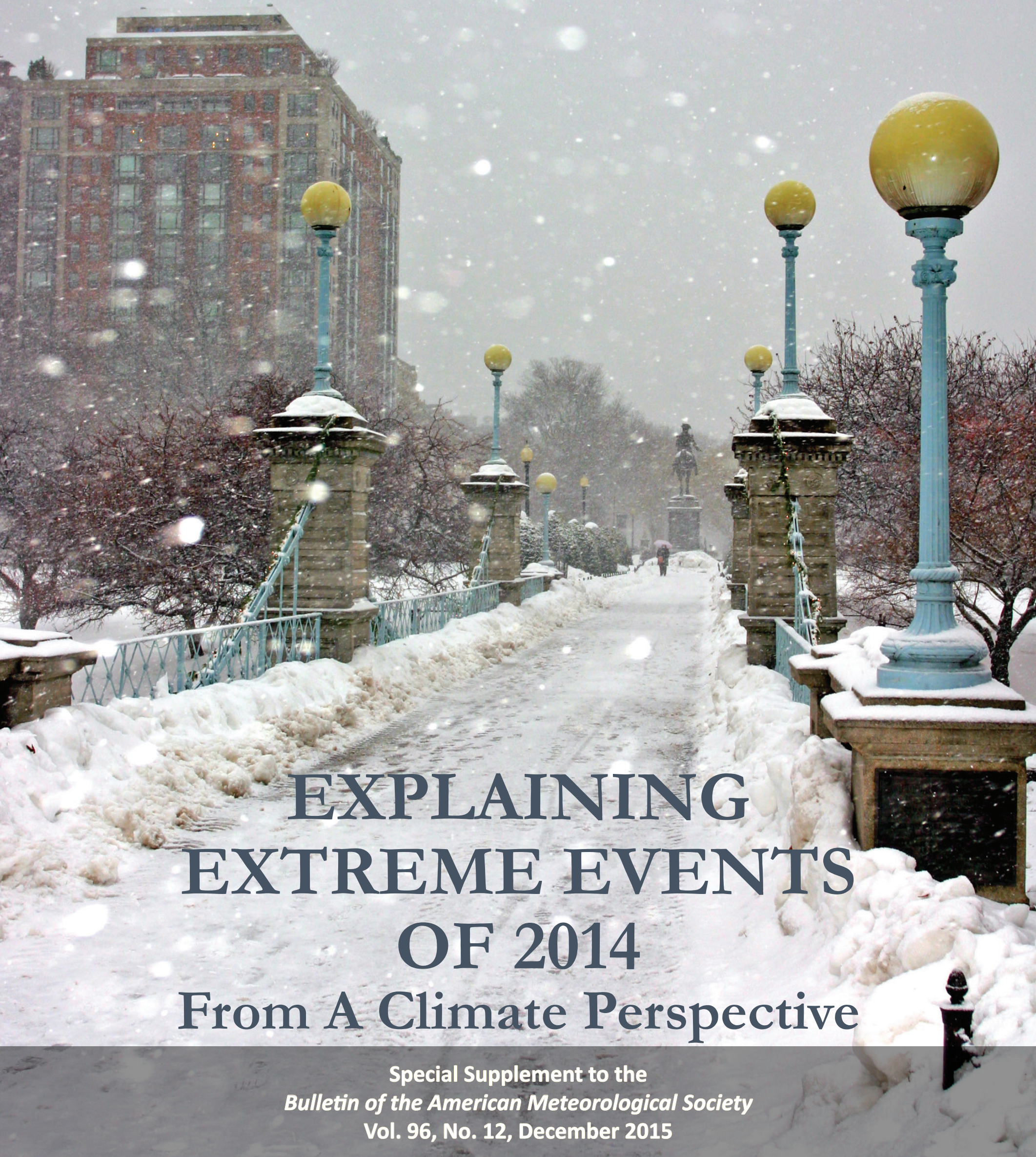




\section{EXPLAINING EXTREME EVENTS OF 20I4 FROM A CLIMATE PERSPECTIVE}

\section{Editors}

Stephanie C. Herring, Martin P. Hoerling, James P. Kossin, Thomas C. Peterson, and Peter A. Stott

Special Supplement to the

Bulletin of the American Meteorological Society

Vol. 96, No. I2, December 2015 
CORRESPONDING EDITOR:

Stephanie C. Herring, PhD

NOAA National Centers for Environmental Information

325 Broadway, E/CC23, Rm IB-I3I

Boulder, CO 80305-3328

E-mail: stephanie.herring@noaa.gov

COVER CREDITS:

Front: (CiStockphotos.com/coleong-Winter snow, Boston, Massachusetts, United States.

BACK: (iStockphotos.com/nathanphoto-Legget, California, United States - August 13, 20I4: CAL FIRE helicopter surveys a part of the Lodge Fire, Mendocino County.

\section{HOW TO CITE THIS DOCUMENT}

Citing the complete report:

Herring, S. C., M. P. Hoerling, J. P. Kossin, T. C. Peterson, and P. A. Stott, Eds., 20I5: Explaining Extreme Events of 2014 from a Climate Perspective. Bull. Amer. Meteor. Soc., 96 (I2), SI-SI72.

Citing a section (example):

Yoon, J. H., S.-Y. S. Wang, R. R. Gillies, L. Hipps, B. Kravitz, and P. J. Rasch, 20I5: Extreme fire season in California: A glimpse into the future? [in "Explaining Extremes of 20I4 from a Climate Perspective”]. Bull. Amer. Meteor. Soc., 96 (I2), S5-S9.

\section{EDITORIAL AND PRODUCTION TEAM}

Riddle, Deborah B., Lead Graphics Production, NOAA/NESDIS National Centers for Environmental Information,

Asheville, NC

Love-Brotak, S. Elizabeth, Graphics Support, NOAA/NESDIS National Centers for Environmental Information,

Asheville, NC

Veasey, Sara W., Visual Communications Team Lead, NOAA/ NESDIS National Centers for Environmental Information, Asheville, NC

Griffin, Jessicca, Graphics Support, Cooperative Institute for Climate and Satellites-NC, North Carolina State University, Asheville, NC

Maycock, Tom, Editorial Support, Cooperative Institute for Climate and Satellites-NC, North Carolina State University, Asheville, NC
Misch, Deborah J., Graphics Support, LMI Consulting, Inc., NOAA/NESDIS National Centers for Environmental Information, Asheville, NC

Osborne, Susan, Editorial Support, LMI Consulting, Inc., NOAA/NESDIS National Centers for Environmental Information, Asheville, NC

Schreck, Carl, Editorial Support, Cooperative Institute for Climate and Satellites-NC, North Carolina State University, and NOAA/NESDIS National Centers for Environmental Information, Asheville, NC

Sprain, Mara, Editorial Support, LAC Group, NOAA/NESDIS National Centers for Environmental Information, Asheville, NC

Young, Teresa, Graphics Support, STG, Inc., NOAA/NESDIS National Centers for Environmental Information, Asheville, NC 
Abstract.

I. Introduction to Explaining Extreme Events of 2014 from a Climate Perspective .................................

2. Extreme Fire Season in California: A Glimpse Into the Future? …………………..................................

3. How Unusual was the Cold Winter of 2013/14 in the Upper Midwest?............................................10

4. Was the Cold Eastern Us Winter of 2014 Due to Increased Variability? .............................................15

5. The 2014 Extreme Flood on the Southeastern Canadian Prairies .................................................... 20

6. Extreme North America Winter Storm Season of 2013/14: Roles of Radiative Forcing and the Global Warming Hiatus.......................................................................................................................... 25

7. Was the Extreme Storm Season in Winter 2013/14 Over the North Atlantic and the United Kingdom Triggered by Changes in the West Pacific Warm Pool?.

8. Factors Other Than Climate Change, Main Drivers of 2014/15 Water Shortage in Southeast Brazil..

9. Causal Influence of Anthropogenic Forcings on the Argentinian Heat Wave of December 2013

10. Extreme Rainfall in the United Kingdom During Winter 2013//4: The Role of Atmospheric Circulation and Climate Change...

II. Hurricane Gonzalo and its Extratropical Transition to a Strong European Storm.............................5I

12. Extreme Fall 2014 Precipitation in the Cévennes Mountains ........................................................ 56

13. Record Annual Mean Warmth Over Europe, the Northeast Pacific, and the Northwest Atlantic During 2014: Assessment of Anthropogenic Influence.

14. The Contribution of Human-Induced Climate Change to the Drought of 2014 in the Southern

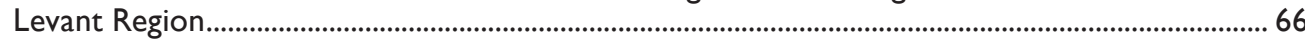

15. Drought in the Middle East and Central-Southwest Asia During Winter 2013/14............................ I

16. Assessing the Contributions of East African and West Pacific Warming to the 2014 Boreal Spring East African Drought

17. The 2014 Drought in the Horn of Africa: Attribution of Meteorological Drivers.

18. The Deadly Himalayan Snowstorm of October 2014: Synoptic Conditions and Associated Trends

19. Anthropogenic Influence on the 2014 Record-Hot Spring in Korea ................................................ 95

20. Human Contribution to the 2014 Record High Sea Surface Temperatures Over the Western Tropical And Northeast Pacific Ocean.

21. The 2014 Hot, Dry Summer in Northeast Asia .............................................................................. 105

22. Role of Anthropogenic Forcing in 2014 Hot Spring in Northern China........................................... III

23. Investigating the Influence of Anthropogenic Forcing and Natural Variability on the 2014 Hawaiian Hurricane Season.

24. Anomalous Tropical Cyclone Activity in the Western North Pacific in August 2014 .................. 120

25. The 2014 Record Dry Spell at Singapore: An Intertropical Convergence Zone (ITCZ) Drought.

26. Trends in High-Daily Precipitation Events in Jakarta and the Flooding of January 2014 ................13।

27. Extreme Rainfall in Early July 2014 in Northland, New Zealand-Was There an Anthropogenic Influence?

28. Increased Likelihood of Brisbane, Australia, G20 Heat Event Due to Anthropogenic Climate Change.

29. The Contribution of Anthropogenic Forcing to the Adelaide and Melbourne, Australia, Heat Waves of January 2014

30 Contributors to the Record High Temperatures Across Australia in Late Spring 2014 ............... 149

3I. Increased Risk of the 20I4 Australian May Heatwave Due to Anthropogenic Activity................ I54

32. Attribution of Exceptional Mean Sea Level Pressure Anomalies South of Australia in August 2014

33. The 2014 High Record of Antarctic Sea Ice Extent........................................................................ 163

34. Summary and Broader Context....................................................................................................... 168 


\section{ABSTRACT_Stephanie C. Herring, Martin P. Hoerling, James P. Kossin, Thomas C. Peterson, and Peter A. Stott}

Understanding how long-term global change affects the intensity and likelihood of extreme weather events is a frontier science challenge. This fourth edition of explaining extreme events of the previous year (2014) from a climate perspective is the most extensive yet with 33 different research groups exploring the causes of 29 different events that occurred in 2014. A number of this year's studies indicate that human-caused climate change greatly increased the likelihood and intensity for extreme heat waves in 2014 over various regions. For other types of extreme events, such as droughts, heavy rains, and winter storms, a climate change influence was found in some instances and not in others. This year's report also included many different types of extreme events. The tropical cyclones that impacted Hawaii were made more likely due to human-caused climate change. Climate change also decreased the Antarctic sea ice extent in 2014 and increased the strength and likelihood of high sea surface temperatures in both the Atlantic and Pacific Oceans. For western U.S. wildfires, no link to the individual events in 2014 could be detected, but the overall probability of western U.S. wildfires has increased due to human impacts on the climate.
Challenges that attribution assessments face include the often limited observational record and inability of models to reproduce some extreme events well. In general, when attribution assessments fail to find anthropogenic signals this alone does not prove anthropogenic climate change did not influence the event. The failure to find a human fingerprint could be due to insufficient data or poor models and not the absence of anthropogenic effects.

This year researchers also considered other humancaused drivers of extreme events beyond the usual radiative drivers. For example, flooding in the Canadian prairies was found to be more likely because of human land-use changes that affect drainage mechanisms. Similarly, the Jakarta floods may have been compounded by land-use change via urban development and associated land subsidence. These types of mechanical factors reemphasize the various pathways beyond climate change by which human activity can increase regional risk of extreme events. 


\title{
12. EXTREME FALL 20I4 PRECIPITATION IN THE CÉVENNES MOUNTAINS
}

\author{
R. Vautard, G.-J. van Oldenborgh, S. Thao, B. Dubuisson, G. Lenderink, A. Ribes, S. Planton, \\ J.-M. SOUBEYROUX, AND P. YIOU
}

Extreme daily fall precipitation in the Cévennes mountains has very likely intensified. The probability of amounts witnessed in 2014 is estimated to have tripled since 1950, with large uncertainties.

Introduction. Fall thunderstorms along the northern Mediterranean coast can produce a few hundred millimeters of precipitation within one day (Ducrocq et al. 2014). Such extremes, also called "Mediterranean events", occurred repeatedly during the fall (September-November, SON) of 2014, triggering 12 severe weather warnings from Météo-France, and inducing floods and casualties in several places during the season. The yearly number of events with precipitation exceeding $100 \mathrm{~mm}$ in a day does not exhibit a significant long-term trend, and furthermore it has been difficult to establish a significant trend in the most extreme cases of each year (Soubeyroux et al. 2015). Here we investigate trends in the fall seasonal maximum of daily precipitation, using a homogenized and quality-controlled dataset. We focus on a specific area, the Cévennes mountain range, where the highest daily precipitation amount is found in France in the fall (Fig. 12.1a). These phenomena are triggered by moist air advected from the warm Mediterranean Sea, hitting the mountain range with convection possibly amplified by colder continental air aloft.

Data. Recently, a homogenized dataset of monthly temperature and precipitation covering continental France was constructed (Gibelin et al. 2014) using the HOMER software (Mestre et al. 2013). A few statistical methods exist to help homogenize daily climate

AFFILIATIONS: VAUTARD AND YIOU-Laboratoire des Sciences du Climat et de l'Environnement-Institut Pierre-Simon Laplace (LSCE-IPSL), Commissariat for Atomic Energy and Alternative Energies (CEA)/National Centre for Scientific Research (CNRS)/ University of Versailles Saint-Quentin (UVSQ), Gif sur Yvette, France; van OLDENBORGH AND LeNDERINK-Royal Netherlands Meteorological Institute (KNMI), De Bilt, Netherlands; THAO, RiBES, AND PLANTON-National Centre for Meteorological Research-Research Group of Atmospheric Meteorology (CNRMGAME), Toulouse, France; Dubuisson AND SoubeYroux-MétéoFrance, Toulouse, France

DOI:I0.II75/BAMS-D-15-00088.I data for temperature and precipitation but generally require specific conditions (close well-correlated neighbor series, e.g., SPLIDHOM, Mestre et al. 2011). For the analysis, we used a set of 27 quality controlled daily series of rain gauge measurements from MétéoFrance daily reference series (DRS) datasets. The DRS are not corrected, but selected using quality information from monthly homogenization (little amplitude and adjustments of inhomogeneities), low daily values missing rate and few successive relocations (Moisselin and Dubuisson 2006). The daily records of DRS are then used without any adjustment.

Most daily series start between 1950 and 1953. The fall precipitation events are small-scale, a few kilometers across but more coherent along the direction of motion, inducing a large spatial variability of seasonal maxima. This creates an observational difficulty as a loose network of rain gauges may miss some events. In order to improve independence among stations, and to have a sample of sites with comparable climatology, we selected a subsample of the rain gauges with the following conditions: (i) the long-term mean of the highest daily precipitation in fall was in the range 70-110 mm day ${ }^{-1}$, (ii) the correlation of any two series was below $0.70\left(\mathrm{r}^{2}<0.5\right)$; in this set the highest 10 precipitation events occur on different days. This leaves 14 rain gauge series (see list in Fig. 12.1b) with 926 station years that we can assume to be identically distributed because of this selection criterion, allowing us to better estimate long return times with extreme value theory. However, the season maxima observed the same year are statistically dependent among locations, which has to be taken into account for statistical inference. We verified that fall maxima are uncorrelated from year to year.

Analysis of fall maxima and their trends. Figure $12.1 \mathrm{~b}$ shows the time series of each of the 14 stations' fall maxima of daily precipitation amounts. The figure 
(a)

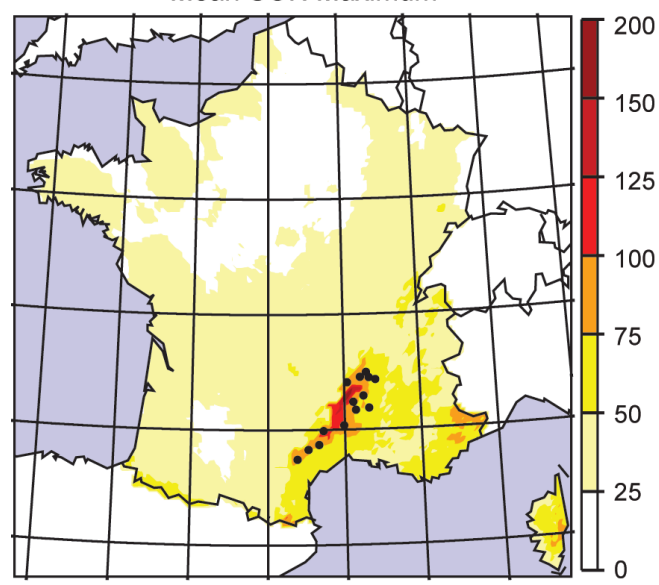

(b)

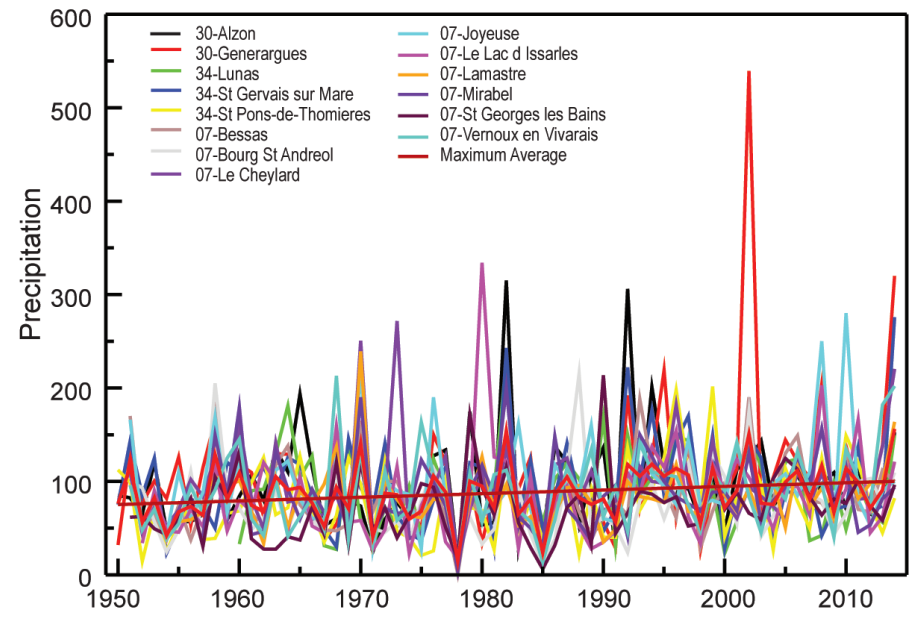

(c)

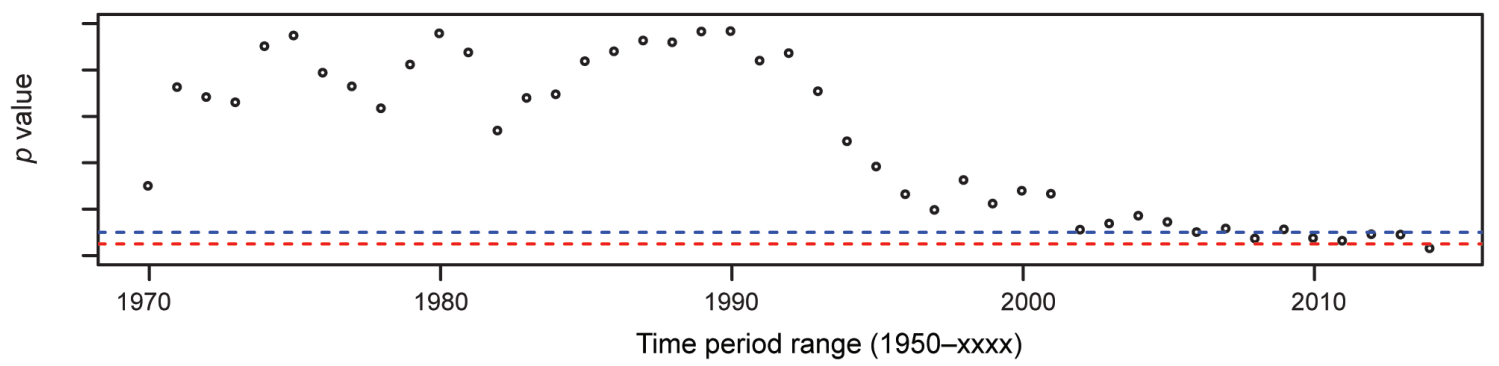

FIG. 12.I. (a) Mean SON maxima of daily precipitation amounts $\left(\mathrm{mm}^{\mathrm{day}} \mathrm{-}^{-1}\right)$ as obtained from the SAFRAN (Système d'Analyze Fournissant des Renseignements Atmosphériques à la Neige) reanalysis (Quintana-Segui et al. 2008), together with the locations of the stations used in the analysis; (b) Individual time series of SON seasonal maxima of daily amounts for each selected site, together with the series of average of these maxima. (c) Two-sided $p$ values obtained for the trend in the SON maximum averaged over the 14 stations, using a time period ranging from 1950 to the value in abscissa.

also shows the yearly average and maximum value found in this subset. The maximum rainfall amount found in the rain gauge set in 2014 is $320 \mathrm{~mm}^{\text {day }}{ }^{-1}$. This value was exceeded only in 2002 and 1980, with total values of $539 \mathrm{~mm} \mathrm{day}^{-1}$ and $334 \mathrm{~mm}^{\text {day }}{ }^{-1}$ (see Fig. 12.1b). The highest seasonal mean of the 14 station maxima is observed in 2014 with $156 \mathrm{~mm}^{\text {day }}{ }^{-1}$.

Average seasonal maxima have a trend of about $4 \%$ decade $^{-1}$, with a two-sided significance of $p \sim 5 \%$ using all years, but $p$ has a more robust value of $10 \%$ when excluding 2014 (see Fig. 12.1c). Individual series trends, calculated using all available years, vary between 0 and $10 \%$ decade $^{-1}$, with median values around $4 \%-5 \%$ decade $^{-1}$, and none of them is negative. However, only two stations have trends with $p$ less than 5\% (Fig. 12.2a). To compare all stations over a common 50-year period we also calculated trends over the period 1965-2014 and found similar, and in fact more often larger than smaller positive trends than in the full data series (Fig. 12.2a).

Pooled time-dependent return period analysis. To estimate changes in return periods, we pooled all 14 station years and fitted an extreme value function to the resulting dataset that depends on a time-varying covariate. We modeled the time series with a Gumbel distribution after transforming the precipitation with a power $2 / 3$ to compensate the expected power $3 / 2$ scaling that results from three factors that each contribute a scaling $1 / 2$ to extreme precipitation in the Gaussian approximation: the mass flux, specific humidity and precipitation efficiency (Wilson and Toumi 2005; van den Brink and Können 2011). The shape and scale parameters are assumed to vary together with the global mean temperature, as a covariate to simulate climate change. Uncertainties are 
(a)

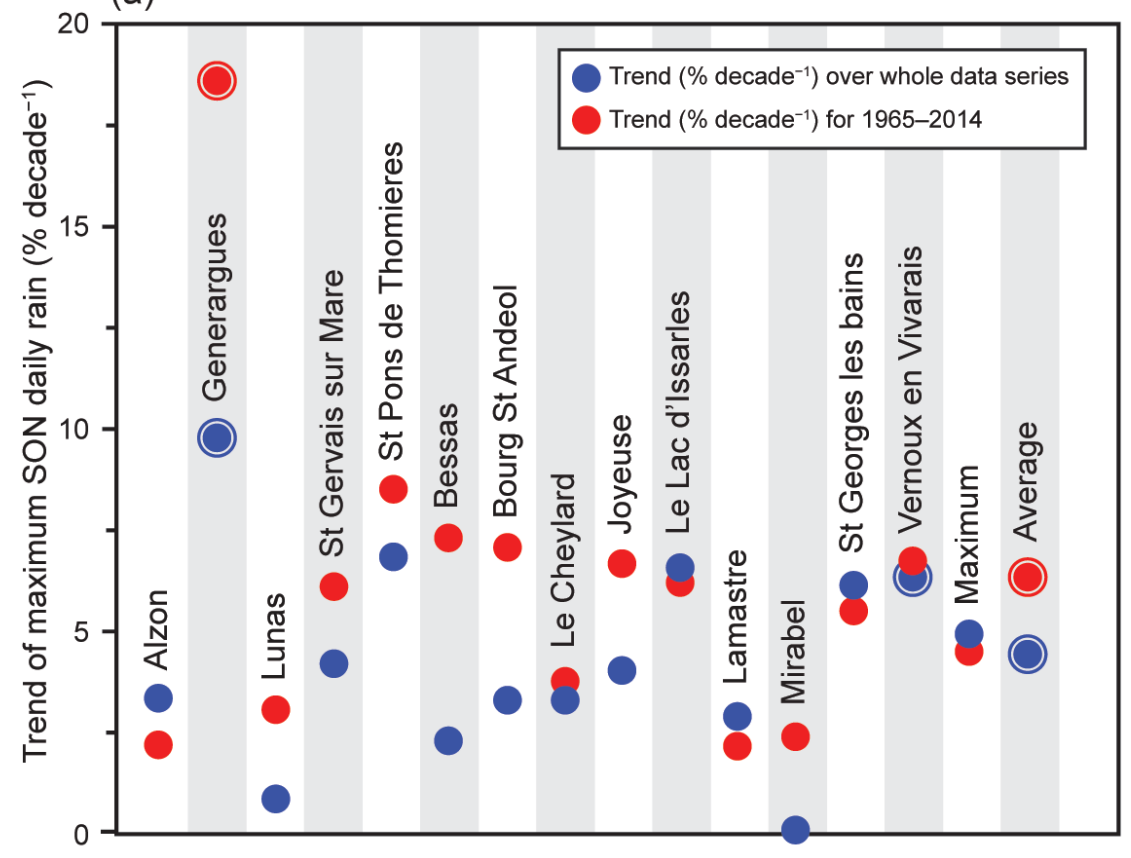

(b) SON stations precipitation 1950:2013 (99.70\% Cl)

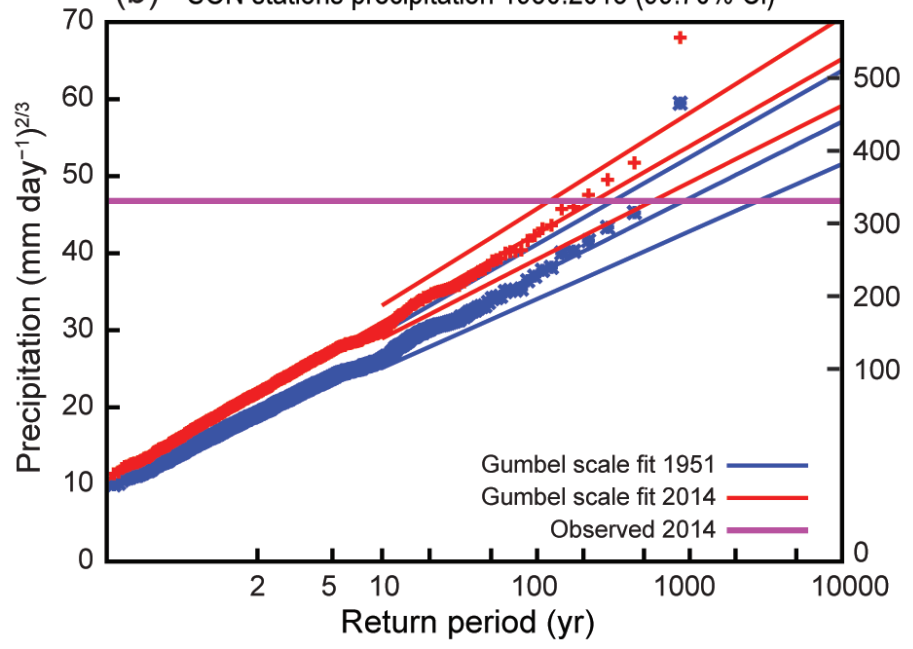

(c)

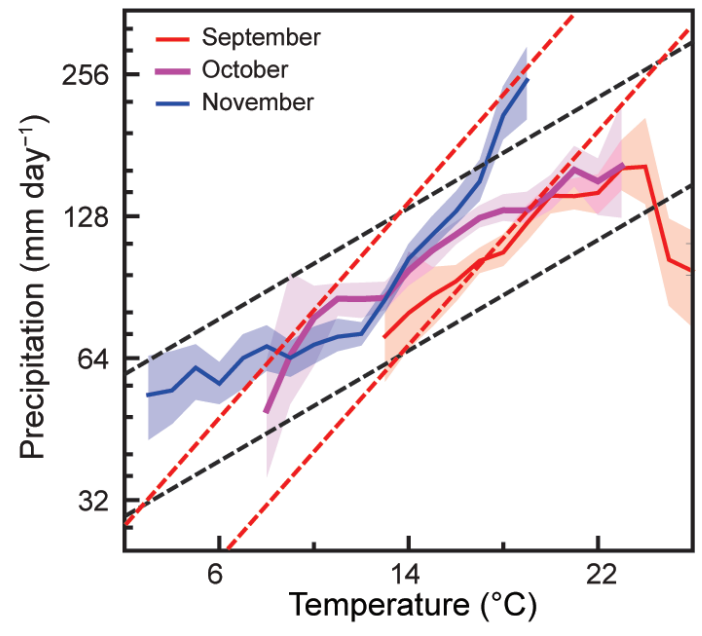

Fig. 12.2. (a) Trend values (\% decade-I) for each rain gauge SON maximum, the average (calculated from 1950 on; circled point). Red points show the values obtained from the same analysis but over the 50-year 1965-2014 period. Circled points are those having a two-sided $p$ value exceeding $5 \%$. (b) Fit of a time-dependent Gumbel distribution to the fall maximum of precipitation of the 865 station years to the power $2 / 3$. The position and scale parameters of the Gumbel distribution are assumed to scale with the smoothed global mean temperature. The red lines indicate the fit for the climate of 2014 with one-sided $95 \%$ confidence interval, taking spatial dependencies into account to first order, the blue lines the same for 1950. The observations are also plotted twice: once shifted up with the fitted trends to 2014, once shifted down to 1950. The horizontal line denotes the value observed in 2014. (c) Dependency of the 99 th percentile of daily precipitation on wet-days (and $5 \%$ to $95 \%$ uncertainty range) on daily mean $\left(43.5^{\circ}-45^{\circ} \mathrm{N}, 2.5^{\circ}-5^{\circ} \mathrm{E}\right.$ average) temperature $\left({ }^{\circ} \mathrm{C}\right)$ from $\mathrm{E}-\mathrm{OBS}$ (Haylock et al. 2008) for stations below $61 \mathrm{I} \mathrm{m}$, dotted black (red) lines denote Clausius-Clapeyron (two times CC) scaling. The method is described in Lenderink et al. (2011).

estimated by a non-parametric bootstrap. To account for stations dependence, we used, in the calculation of significance, an equivalent number of degrees of freedom $\mathrm{N}^{\star}=3.2$ (instead of 14 for the number of sites), derived from the analysis of pooled trends, and consistent with the range of values suggested in Bretherton et al. (1999). This has been implemented in the bootstrap by scaling the p-value. From this 
analysis, the fitted return time of the value of fall 2014 in the current climate is about 250 years (Fig. $12.2 \mathrm{a}$, with uncertainty range $120-600$ years) at a given location. This translates to an event like the 2014 amounts every 10-40 years at any of the 14 stations. We estimate that around 1950 the return time would have been a factor three higher, with a lower bound of the $90 \%$ confidence interval of 1.15 .

Attribution. The increase found in intensities of extreme daily precipitation can, in principle, be caused by a variety of mechanisms (natural variability, changes in climate forcings). Anthropogenic climate change is an obvious candidate, but low-frequency natural variability and changing aerosol loads can also have played a role. This can only be investigated using a climate model able to reproduce precipitation extremes. However, hydrostatic global and regional climate models have problems representing the tail of the distribution well in particular for precipitation of convective origin (Chan et al 2014) and long simulations of non-hydrostatic models are not yet available. We therefore resort to a statistical model relating extreme daily convective precipitation to the local temperature in areas with ample moisture availability (Lenderink and van Meijgaard 2008; Lenderink et al 2011). The wet-day 99th percentile of daily precipitation for the individual months, September to November, shows a robust increase with temperature, except for the highest temperatures in September (Fig. 12.2b). Excepting these, this increase follows a dependency of $7 \%-14 \%$ of precipitation amount per degree, in correspondence to one to two times the Clausius-Clapeyron (CC) relation-a behavior also obtained for the 99.9th percentile (Fig. 12.2c). The observed increase of precipitation extremes with temperature can be understood by the moisture increase. The enhanced scaling compared to the Clausius-Clapeyron relation can be explained by convective cloud feedbacks to increasing moisture levels (see Westra et al. 2014 for a review on scaling). Lenderink and van Meijgaard (2008) also found an enhancement of short-term precipitation extremes with sea surface temperature of $14 \%$ per degree in The Netherlands.

September temperatures in this region have increased about $50 \%$ faster than the global mean temperature over 1950-2014 (not shown), so temperatures are about $1.1^{\circ} \mathrm{C}$ higher now than they were around 1950. This agrees very well with results from the CMIP5 ensemble in Mediterranean areas (Stocker et al. 2013). Using the scaling found above the warming trend translates into an increase in intensity of extreme daily precipitation of roughly $7 \%-14 \%$. This indicates that at least part of the observed increase of precipitation extremes is attributable to the increase in temperature in the region, which in turn has been attributed to anthropogenic modification of the atmospheric composition (e.g., Stocker et al. 2013). However, given the large uncertainties and the unknown influences of other factors such aerosol changes that may have influenced precipitation extremes we cannot directly attribute trends to atmospheric composition changes.

Conclusion. Extreme precipitation in the Cévennes mountains in the fall of 2014 reached more than $300 \mathrm{~mm}$ in a day and induced a record (since 1950) maximal intensity when averaged over an ensemble of rain gauges. Our analysis shows a strong increase of the fall maxima in this area of about $30 \%$ since the middle of the 20th century, with trends of about $4 \%$ decade $^{-1}(p \sim 10 \%)$. The return period of events such as those found in 2014 is estimated to having been reduced by a factor of about three, with a $90 \%$ confidence lower bound of 1.15. In this area heavy precipitation increases as a function of regional temperature, with a rate exceeding $7 \%{ }^{\circ} \mathrm{C}^{-1}$, indicating that at least part of the trend is due to warming. While suggesting a human influence, a formal attribution of these trends, using non-hydrostatic models, would be required for establishing and quantifying the fraction of attributable risk, since other factors may have entered into play in this area such as changes in aerosol loads, radiation, and natural variability.

ACKNOWLEDGEMENTS. This study was supported by the French Ministry of Ecology, Sustainable Development and Energy, through the national climate change adaptation plan project EXTREMOSCOPE, and by the FP7 EUCLEIA project under Grant \# 607085.

\section{REFERENCES}

Bretherton, C. S., M. Widmann, V. P. Dymnikov, J. M. Wallace, and I. Bladé, 1999: The effective number of spatial degrees of freedom of a time-varying field. $J$. Climate, 12, 1990-2009.

Chan, S. C., E. J. Kendon, H. J. Fowler, S. Blenkinsop, N. M. Roberts, and C. A. T. Ferro, 2014: The value of high-resolution Met Office regional climate models in the simulation of multihourly precipitation extremes. J. Climate, 27, 6155-6174, doi:10.1175 /JCLI-D-13-00723.1. 
Ducrocq, V., and Coauthors, 2014: HyMeX-SOP1: The field campaign dedicated to heavy precipitation and flash flooding in the northwestern Mediterranean. Bull. Amer. Meteor. Soc., 95, 1083-1100, doi:10.1175 /BAMS-D-12-00244.1.

Gibelin, A. L., and Coauthors, 2014: Evolution de la température en France depuis les années 1950: Constitution d'un nouveau jeu de séries homogénéisées de référence (Evolution of temperature in France since the 1950s: Constitution of a new reference dataset of homogenized time series). La Météorologie, 87, 45-53, doi:10.4267/2042/54336.

Haylock, M. R., N. Hofstra, A. M. G. Klein Tank, E. J. Klok, P. D. Jones, and M. New. 2008: A European daily high-resolution gridded dataset of surface temperature and precipitation. J. Geophys. Res., 113, D20119, doi:10.1029/2008JD10201.

Lenderink, G., and E. van Meijgaard, 2008: Increase in hourly precipitation extremes beyond expectations from temperature changes. Nat. Geosci., 1, 511-514, doi:10.1038/ngeo262.

-, H. Y. Mok, T. C. Lee, and G. J. van Oldenborgh, 2011: Scaling and trends of hourly precipitation extremes in two different climate zones - Hong Kong and the Netherlands. Hydrol. Earth Syst. Sci., 15, 3033-3041, doi:10.5194/hess-15-3033-2011.

Mestre, O., C. Gruber, C. Prieur, H. Caussinus, and S. Jourdain, 2011: SPLIDHOM: A method for homogenization of daily temperature observations. J. Appl. Meteor. Climatol., 50, 2343-2358 doi:10.1175/2011JAMC2641.1.

— , and Coauthors, 2013: HOMER: A homogenization software - methods and applications. Időjárás, Quart. J. Hung. Meteor. Serv., 117, 47-67.

Moisselin, J.-M., and B. Dubuisson, 2006: Évolution des valeurs extrêmes de température et de précipitations au cours du XXe siècle en France (Evolution of extremes of temperature and precipitations during the 20th century in France). La Météorologie, 54, 33-42, doi:10.4267/2042/20099.

Quintana-Seguí, P., and Coauthors, 2008: Analysis of near-surface atmospheric variables: Validation of the SAFRAN analysis over France. J. Appl. Meteor. Climatol., 47, 92-107, doi:10.1175/2007JAMC1636.1.

Soubeyroux, J.-M., L. Neppel, J.-M. Veysseire, Y. Tramblay, J. Carreau, and V. Couget, 2015: Evolution des précipitations extrêmes en France en contexte de changement climatique (Evolution of extreme rainfall in France with a changing climate). La Houille Blanche, 1, 27-33, doi:10.1051/lhb/2015004.
Stocker, T. F., and Coauthors, Eds., 2013: Climate Change 2013: The Physical Science Basis. Cambridge University Press, 1535 pp. [Available online at www .climatechange2013.org/images/report/WG1AR5 _ALL_FINAL.pdf.]

van den Brink, H. W., and G. P. Können, 2011: Estimating 10000-year return values from short time series. Int. J. Climatol., 31, 115-126, doi:10.1002/joc.2047.

Westra, S., and Coauthors, 2014: Future changes to the intensity and frequency of short-duration extreme rainfall. Rev. Geophys., 52, 522-555, doi:10.1002/2014RG000464.

Wilson, P. S., and R. Toumi, 2005: A fundamental probability distribution for heavy rainfall. Geophys. Res. Lett., 32, L14812, doi:10.1029/2005GL022465. 


\begin{tabular}{|c|c|c|c|}
\hline \multicolumn{4}{|c|}{ ON EVENT STRENGTH † } \\
\hline & INCREASE & DECREASE & NOT FOUND OR UNCERTAIN \\
\hline Heat & $\begin{array}{l}\text { Australia (Ch. 3l) } \\
\text { Europe (Ch. 13) } \\
\text { S. Korea (Ch. 19) }\end{array}$ & & $\begin{array}{l}\text { Australia, Adelaide \& Melbourne } \\
\text { (Ch. 29) } \\
\text { Australia, Brisbane (Ch.28) }\end{array}$ \\
\hline Cold & & Upper Midwest (Ch.3) & \\
\hline $\begin{array}{l}\text { Winter } \\
\text { Storms and } \\
\text { Snow }\end{array}$ & & & $\begin{array}{l}\text { Eastern U.S. (Ch. 4) } \\
\text { N. America (Ch. 6) } \\
\text { N. Atlantic (Ch. 7) }\end{array}$ \\
\hline $\begin{array}{c}\text { Heavy } \\
\text { Precipitation }\end{array}$ & Canada** (Ch. 5) & & $\begin{array}{l}\text { Jakarta**** (Ch. 26) } \\
\text { United Kingdom } * * * *(C h .10) \\
\text { New Zealand (Ch. 27) }\end{array}$ \\
\hline Drought & $\begin{array}{l}\text { E. Africa (Ch. 16) } \\
\text { E. Africa* (Ch. 17) } \\
\text { S. Levant (Ch. 14) }\end{array}$ & & $\begin{array}{l}\text { Middle East and S.W. Asia } \\
\text { (Ch. I5) } \\
\text { N.E. Asia (Ch. 2I) } \\
\text { Singapore (Ch. 25) }\end{array}$ \\
\hline $\begin{array}{l}\text { Tropical } \\
\text { Cyclones }\end{array}$ & & & $\begin{array}{l}\text { Gonzalo (Ch. II) } \\
\text { W. Pacific (Ch. 24) }\end{array}$ \\
\hline Wildfires & & & California (Ch. 2) \\
\hline $\begin{array}{l}\text { Sea Surface } \\
\text { Temperature }\end{array}$ & $\begin{array}{l}\text { W. Tropical \& N.E. Pacific (Ch. 20) } \\
\text { N.W. Atlantic \& N.E. Pacific (Ch. 13) }\end{array}$ & & \\
\hline $\begin{array}{l}\text { Sea Level } \\
\text { Pressure }\end{array}$ & S. Australia (Ch. 32) & & \\
\hline $\begin{array}{l}\text { Sea Ice } \\
\text { Extent }\end{array}$ & & & Antarctica (Ch. 33) \\
\hline
\end{tabular}

† Papers that did not investigate strength are not listed.

t† Papers that did not investigate likelihood are not listed.

* No influence on the likelihood of low rainfall, but human influences did result in higher temperatures and increased net incoming radiation at the surface over the region most affected by the drought.

** An increase in spring rainfall as well as extensive artificial pond drainage increased the risk of more frequent severe floods from the enhanced rainfall.

*** Evidence for human influence was found for greater risk of UK extreme rainfall during winter 2013/14 with time scales of 10 days

***** The study of Jakarta rainfall event of 2014 found a statistically significant increase in the probability of such rains over the last 115 years, though the study did not establish a cause. 


\title{
ON EVENT LIKELIHOOD ††
}

Argentina (Ch. 9)

Australia (Ch. 30, Ch. 31)

Australia, Adelaide (Ch. 29)

Australia, Brisbane (Ch. 28)

Melbourne, Australia (Ch. 29)

Europe (Ch. 13)

S. Korea (Ch. 19)

China (Ch. 22)

Cold
Winter
Storms and
Snow

Heavy
Precipitation

(a)

N. America (Ch. 6)

S. France (Ch. 12)

Middle East and S.W. Asia (Ch. 15)

Drought

E. Africa (Ch. 16)

S. Levant (Ch. 14)

E. Africa* (Ch. 17)

N.E. Asia (Ch. 2I)

Wildfires

\author{
California (Ch. 2)
}

\section{W. Tropical \& N.E. Pacific}

Sea Surface

Temperature

(Ch. 20)

N.W. Atlantic \& N.E. Pacific (Ch. 13)

Sea Level

Pressure

S. Australia (Ch. 32)

Sea Ice

Extent

.

Antarctica (Ch. 33)

† Papers that did not investigate strength are not listed.

t† Papers that did not investigate likelihood are not listed.

* No influence on the likelihood of low rainfall, but human influences did result in higher temperatures and increased net incoming radiation at the surface over the region most affected by the drought.

** An increase in spring rainfall as well as extensive artificial pond drainage increased the risk of more frequent severe floods from the enhanced rainfall.

*** Evidence for human influence was found for greater risk of UK extreme rainfall during winter 2013/14 with time scales of 10 days

***** The study of Jakarta rainfall event of 2014 found a statistically significant increase in the probability of such rains over the last II5 years, though

the study did not establish a cause. 